\title{
JUURNAL.RU
}

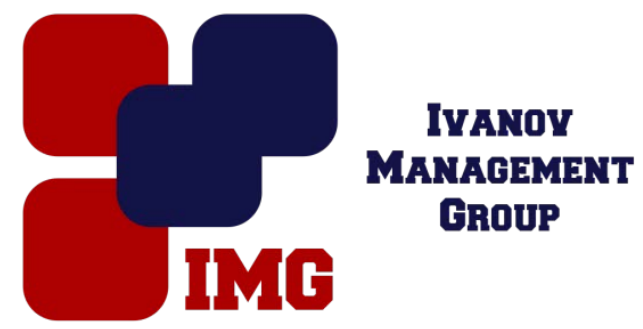

Соболева И.А. НУЗ Дорожная клиническая больница на ст. Ростов-Главный ОАО «РЖД» Ростов-на-Дону, Россия

doi: 10.18411/lj-25-12-2016-1-11

idsp 000001:lj-25-12-2016-1-11

\section{Консервативное лечение хронического тонзиллита как профилактика метатонзиллярных заболеваний}

Хронический тонзиллит - это комплексная реакция организма на наличие инфекционного очага. По современной классификации выделяют 2 формы хронического тонзиллита: компенсированную и декомпенсированную. Признаками декомпенсации являются присоединение метатонзиллярных заболеваний: полиартрита, ревматизма, миокарда, нефрита, а также стойкого субфебриллитета и других проявлений интоксикации, возникновение паратонзиллярных абсцессов.

В 2005-2007 гг. наметился ежегодный прирост первичной заболеваемости и распространенности ревматических болезней сердца, включая острую ревматическую лихорадку, как в нашей стране $[1,2,3]$, так и за рубежом $[4,5]$ причем количество осложнений остается наибольшим среди подростков и взрослых. Основными причинами роста декомпенсированных форм хронического тонзиллита являются ослабление внимания к диспансеризации этой группы больных и снижение хирургической активности $[6,7,8]$, а также рост антропогенного загрязнения окружающей среды $[9,10]$.

Существенную роль в профилактике осложнений хронического тонзиллита играет его консервативное лечение в условиях поликлиники [11].

Целью нашего исследования было изучение эффективности комплексного лечения детей с хроническим тонзиллитом.

Материал и методы. В исследовании принимали участие 78 детей в возрасте от 4 до 14 лет с хроническим тонзиллитом, компенсированной формой. 2 раза в год детям проводился курс профилактического лечения хронического тонзиллита. Эффективность лечения оценивали по числу перенесенных в течение года ангин. Сроки наблюдения: от 2,5 до 3,8 лет.

Диагностика хронического тонзиллита основывалась на следующих признаках: 1. тщательный сбор анамнеза (ретроспективный дифференциальный диагноз ангины и острого фарингита) выявил, что средняя частота ангин до лечения составила 3,6 раз за год; 2. выявление местных признаков хронического тонзиллита (гнойное содержимое в лакунах миндалин, регионарный лимфоаденит, 
спаянность с небными дужками, гиперемия и инфильтрация краев дужек, отек надминдаликового пространства) - эти признаки обнаружены у всех исследуемых детей; 3. выявление симптомов сопряженных с хроническим тонзиллитом заболеваний.

У всех исследуемых детей выявлены симптомы интоксикации: периодически субфебрильная температура - у 6 больных, быстрая утомляемость у 24 больных, периодически возникающие боли в суставах и в сердце в период обострения без объективных изменений на ЭКГ - у 18 больных, периодическая головная боль - у 4 больных.

Консервативное лечение проводилось 2 раза в год и включало: местное воздействие на миндалины, общее лечение, обеспечивающее иммуномодулирующее, противовоспалительное действие, физиотерапию.

Промывание лакун небных миндалин проводили через день с использованием растворов антисептиков (мирамистин, водный раствор хлоргексидина, фурациллина). На курс было выполнено по 6-7 процедур.

В качестве препарата, обеспечивающего комплексное иммуномодулирующее и противовоспалительное действие мы избрали Тонзилотрен. Тонзилотрен является комплексным гомеопатическим препаратом, предназначенным для лечения острых и хронических воспалительных процессов в миндалинах.

Лечение препаратом Тонзиллотрен проводилось ступенчато. В острой стадии заболевания, то есть, при наличии ангины, лечение назначали по принципам классической гомеопатии, используя принцип подобия. Ангине всегда присущи признаки воспаления - отек, гиперемия, боль при глотании, отек слизистой оболочки глотки, регионарный лимфоаденит. Поэтому Тонзиллотрен, содержащий Atropinum sulfuricum (D5), Hepar sulfur (D3), Mercurius bijodatus (D8), Kalium bichromicum (D4), Silicea (D2) наиболее подобен всем видам ангин - от катаральной до фолликулярной. При ангине назначали по 1 таблетке каждый час в течение 1-2 суток до получения терапевтического эффекта, затем переходили на прием 3 таблеток в сутки (по 1 таблетке 3 раза в день) - в течение 2 месяцев.

При профилактическом курсе назначали Тонзиллотрен по 1 таблетке 3 раза в день в течение 2 месяцев 2-3 раза в год в межсезонье.

Физиотерапия включала воздействие на небные миндалины терапевтического лазера, а также магнитотерапию на область регионарных лимфатических узлов.

В группе контроля применялся метод промывания лакун миндалин. В эту группу включено18 детей от 7 до 14 лет, поскольку промывание лакун детям более раннего возраста затруднено негативной реакцией пациента.

Критериями эффективности проводимого лечения было уменьшение частоты обострений хронического тонзиллита, исчезновение гнойного содержимого из лакун миндалин, уменьшение гиперемии и инфильтрации небных дужек, уменьшение величины небных миндалин, уменьшение или исчезновение регионарных лимфоузлов.

В результате проведенного лечения средняя частота ангин сократилась до 1,6 раз в год, у всех детей исчезли симптомы интоксикации, отмечено улучшение местного статуса. 
Таким образом, проведение профилактических курсов лечения хронического тонзиллита способствует стиханию клинических признаков заболевания и сокращению числа обострений.

\section{Литература}

1. Казакова Л.М. Острая ревматическая лихорадка // Мать и дитя в Кузбасе. 2007. № 1. С. 7-9.

2. Мустафин Т.И. Анализ статистических показателей при ревматической болезни сердца на региональном уровне //Мед. вестн. Башкортостана. 2010. № 1(5). С. 12-17.

3. Власова Т.М. Бойко Н.В Рост числа постстрептококковых осложнений у больных хроническим тонзиллитом // Российская оториноларингология. 2015. № S1. C. 45-47.

4. Rheumatic fever and rheumatic heart disease // WHO technical report series № 923. Geneva. 2004. P.122.

5. Skorek A., Stodulski D., Stankiewicz C. Severe regional and distant complication of tonsillitis. Case report // Otolaryngol Pol. 2004. N. 5 (58). P. 999-1003.

6. Бойко Н.В., Гукасян Е.Л., Быкова В.В. Статистика хирургических вмешательств при хроническом тонзиллите // Вестник оториноларингологии. 2008. № 5. С. 234.

7. Бойко Н.В., Локшина Л.С., Сорока Г.Г., Бриж Ю.В., Сулина Н.Ю. Изменение подходов к лечению хронического тонзиллита в детском возрасте по материалам Ростовской ЛОР клиники // Вестник оторинолар. 2012. № 5. С. 226.

8. Бойко Н.В., Бачурина А.С., Оксенюк О.С., Колмакова Т.С. Лечение послеоперационного воспаления после тонзиллэктомии у детей // Педиатрия. Журнал им. Г.Н. Сперанского. 2016. № 1 (95). С. 93-96.

9. Колмакова Т.С., Тупиков В.А., Шпак Л.И. Влияние антропогенного загрязнения на здоровье жителей Ростовской области. Мед. вестник Юга России. 2012. № 3. С. 16-18.

10.Белик С.Н., Колмакова Т.С. Влияние антибиотиков, используемых при производстве свинины, на здоровье потребителей второго порядка. В сб: Актуальные проблемы произв свинины в РФ. Матер XXIII засед межвуз коорд совета по свин и междунар науч-практ конф. 2013. С. 106-111.

11.Бойко Н.В., Калинкина М.И., Горшкова Г.И. Консервативное лечение хронического тонзиллита // Детская оториноларингология. 2012. № 3. С. 22-24. 